УДК 378:373.3]:811.161.2’35'271

DOI: $10.15330 /$ esu. $17.229-236$
Валентина Вімюк,

кандидат педагогічних наук,

Східноєвропейський національний університет

імені Лесі Українки (м. Луцьк, Україна)

Valentyna Vitiuk,

Candidate of pedagogical sciences (PhD),

Lesya Ukrainka Eastern European National University

(Lutsk, Ukraine)

vityuk-valentyna@ukr.net

\title{
КУЛЬТУРА МОВЛЕННЯ ЯК ОСНОВА ПРАВОПИСНӦ̈ ГРАМОТНОСТІ МАЙБУТНІХ УЧИТЕЛІВ ПОЧАТКОВОЇ ШКОЛИ
}

\section{THE CULTURE OF SPEECH AS THE BASIS OF SPELLING LITERACY OF FUTURE PRIMARY SCHOOL TEACHERS}

Автор статті наголоиуе на важливості мовно-мовленнсвої підготовки студентів педагогічних вииів на сучасному етапі модернізачії вищої освіти в Україні у контексті концептуальних аспектів Нової української иколи. У статті проаналізовано типові помилки у мовленні майбутніх учителів початкової иколи. Описано суржск, молодіжний сленг, жаргонну лексику в мовленні студентів, висвітлено культуру спілкування в сучасних соиіальних мережах. Презентовано сучасний стан інтернетного спілкування, названо поширені пунктуачійні анормативи, запропоновано сочіальні мережі для вивчення украӥнської літературної мови. Проілюстровано використания ненормативної лексики на текстах художньої літератури сучасних украӥнських письменників. Окреслено основні иляхи вдосконалення культури усного та писемного мовлення сучасної молоді. Автор статті наголоиус, ио студенти педагогічного факультету повини досконало знати норми сучасної украйнської літературної мови, уміти користуватися академічними лінгвістичними словниками украӥнської мови, стежити за правильністю усного та писемного мовлення.

Ключові слова: культура мовлення, правописна грамотність, суржик, сленг, жаргон, інтернетне мовлення.

The author of the article emphasizes the importance of quality training of future primary school teachers in the context of the modernization of the content of education in Ukraine. The article affirms the idea that the professional training of teachers is the current task of higher educational institutions. The stated position of the author is confirmed by the current educational and regulatory documents. The article draws attention to the training of future teachers in the context of the requirements of the National Strategy for the Development of Education in Ukraine for the period up to 2021, the Concept of the New Ukrainian School, which states that the New Ukrainian School requires a successful, motivated, creative teacher, will not only knowledge, and teach them to acquire, independently learn with interest and pleasure. Scientific intelligence highlights the views of leading scholars exploring the issue of teacher training. Justifying the need to improve the system of training future primary school teachers, the author proposes to apply innovative teaching and teaching technologies, in particular, in the process of studying philological disciplines. In particular, the author of the article defines spelling competence as a component of professional competence of students of pedagogical higher educational institutions and believes that one of the priority tasks of philology teachers of higher educational institutions is to train specialists who are well versed and written, have a high level of graphic skills and skills, spelling and punctuation literacy and competency spelling in general.

Key words: modernization of the content of education, integration of national education, vocational training of future teachers, New Ukrainian school, primary school, linguodidactics of higher education, spelling competence, graphic, spelling, punctuation competences. 
Постановка проблеми в загальному вигляді... У контексті концептуальних аспектів Нової української школи зміщуються акценти у професійно-практичній підготовці майбутніх учителів початкової школи, які повинні не тільки досконало володіти технологією власної професії, а й компетентно використовувати мовні ресурси для міжособистісної взаємодії у будь-яких педагогічних ситуаціях. Сучасний учитель Нової української школи має мати неупереджене відчуття мови, бажанням постійно стежити за змінами, що відбуваються в нормах вимови, наголошування, слововживання, правопису, мати високу культуру усного та писемного мовлення, щоб орфографічно й пунктуаційно правильно, граматично й стилістично вправно висловити свої думки, переконливо представити власні інтереси, досягти успіху в майбутній професійній діяльності.

Нині не втрачає своєї значущості рідномовний кодекс І. Огієнка "Наука про рідномовні обов'язки. Рідномовний катехезіс", написаний для українців Галичини й Волині ще в першій половині минулого століття. Обгрунтовуючи необхідність володіння літературним мовленням, методикою навчання рідної мови, І. Огієнко стверджує: "Кожний учитель - якого б фаху він не був - мусить досконало знати свою соборну літературну мову й вимову та соборний правопис" [10, с. 37].

У наш час питання мовленнєвої вправності студентів, їх правописної грамотності набуває особливої актуальності у зв'язку 3 прийняттям нової законодавчої бази щодо української мови, новий Закон України "Про забезпечення функціонування української мови як державноі” (25 квітня 2019 р. № 2704-VIII) [8], та затвердженням нової редакції "Українського правопису" (постанова Кабінету Міністрів України № 437 від 22 травня 2019 р.) [18].

Аналіз останніх досліджень $\boldsymbol{i}$ публікацій... Питання культури мовлення висвітлено у працях О. Авраменка, Б. Антонека-Давидовича, Н. Бабич, С. Срмоленко, А. Коваль, Л. Мацько, В. Мельничайка, О. Пономаріва, О. Сербенської, I. Хом'яка та ін.

Формулювания цілей статmі... Мета статті - проаналізувати типові помилки у мовленні майбутніх учителів початкової школи, окреслити основні шляхи удосконалення культури усного та писемного мовлення сучасної молоді.

Виклад основного матеріалу дослідження... Із поняттям правописна грамотність тісно пов'язане поняття культури мовлення. Культура мовленя - це рівень володіння нормами усної та писемної літературної мови, а також свідоме, цілеспрямоване, майстерне використання мовно-виражальних засобів залежно від мети й обставин спілкування [3].

Проблема формування правильності мовлення майбутнього вчителя $\epsilon$ важливою для сучасної вищої та початкової школи. Слушними з цього приводу $\epsilon$ слова М. Вашуленка, який називає учителів початкових класів "першовчителями рідної мови, наголошуючи, що саме вони є провідниками українського слова, слова висококультурного і високоморального" [4].

На підставі результатів науково-педагогічних спостережень можемо стверджувати, що у мовленні студентів типовими є порушення орфоепічної норми, зокрема, нехтування асиміляційними процесами в українській мові, численними $\epsilon$ акцентуаційні анормативи, проте найбільший пласт у мовленні сучасної молоді становлять лексичні помилки. Це помилки у слововживанні, у виборі слова: неточність вибраного слова (незнання явищ синонімії, паронімії), уживання діалектних i просторічних слів у літературній мові; невмотивоване використання слів різної 
стилістичної приналежності й емоційно-оцінних слів, повтори одного й того ж самого слова чи споріднених слів, неправильне написання слів іншомовного походження та неправильне розуміння значення цих слів і т. под. Значна частина студентів віддає перевагу іншомовному варіанту слова із синонімічного ряду, наслідуючи модні тенденції: консенсус (згода), спонсор (доброчинець), тенерація (покоління) і т. под. Порушенням у мовленні студентів є тавтологічні звороти (письменник написав, промовляе промову та ін.), плеоназми (моя автобіографія, у січні місяиі, обмежений ліміт). Часто порушується точність вираження думки через неправильну лексичну сполучуваність слів: страменно гарний, добра книга та ін.

У наш час поширеними недоліками мовлення студентів $\epsilon$ вживання діалектизмів, жаргонізмів, вульгаризмів, канцеляризмів, слів-паразитів, суржику, сленгу і т. ін. Однією з актуальних проблем українського мовленнєвого середовища $\epsilon$ його забрудненість суржиком, так як мовці не володіють літературними нормами рідної мови. У “Лінгвістичній енциклопедіі”" О. Селіванової суржик визначається як “форма міксації мов, засіб спілкування певної частини населення України, який $\epsilon$ результатом штучного й неприродного поєднання елементів російської та української мов, що порушує норми української літературної мови" [14]. Така тенденція стає можливою через те, що обидві мови близькі за звуковою системою, графікою, граматикою, правописом, способами творення слів.

Суржик заполонив наш мовний простір, спотворив нашу рідну мову і вплинув на духовний та культурний рівень сучасної молоді. Прикро, що і до сьогодні не всі визнають суржик шкідливим явищем, не хочуть позбутися "симптомів цієї доволі затяжної хвороби нашої мови”. Заслуговує на увагу думка В. Радчука про те, що суржик $є$ “гібридом, який тінню супроводжує нашу мову крізь віки, а згідно 3 житловим кодексом мови бородатий суржик за вислугу літ перестає бути квартирантом в оселі і стає господарем" [13, с. 11].

Прагнення молоді підкреслити свою оригінальність i нестандартність у процесі комунікації, бажання бути дотепним, вразити співбесідника яскравістю висловлення, виділитись за допомогою мови між співрозмовниками, самоствердитись, зумовили появу сленгу. Молодій людині важливо не тільки “що сказати", але i “як сказати”, щоб бути цікавим оповідачем. Традиційно сленг визначають як слова i вирази, які використовуються особами певних професій або соціальних спільнот. Виділяють такі різновиди сленгу як: міський, студентський, програмістський, сленг художників, комп'ютерний сленг тощо.

Термін сленг у письмовій формі вперше був зафіксований в Англії у XVIII ст. і використовувався на позначення “незаконної" просторічної лексики. У сучасному мовознавстві не існує однозначної диференціації терміну сленг. За однією 3 версій, англ. slang походить від sling (“метати”, “жбурляти”). У таких випадках згадують архаїчне "to sling one's jaw" - "говорити бурхливі й образливі промови". За іншою версією, "сленг" походить від "slanguage", де початкова літера "s" нібито додана до "language" в результаті зникнення слова "thieves"; тобто спочатку йшлося про арго злочинців-злодіїв "thieves" "language" [11, с. 129].

Український сленг має глибоке національне підгрунтя. Національно-мовне обличчя молодіжного сленгу реалізується у тому, що об'єктом сленгової мовотворчості виступають реалії, поняття, постаті української дійсності. На думку дослідниці Л. Ставицької, “сучасний молодіжний сленг $є$ ніби посередником між інтержаргоном та мовною практикою народу, розмовно-побутовою мовою широких верств населення, яка послуговувалась і завжди послуговуватиметься здатністю української 
мови до продукування стилістично знижених, іронічних, гротескних лексичних засобів, що в сучасних умовах демократизації стилів спілкування $\mathrm{i}$ виявляються адекватними жаргонним і сленговим номінаціям" [16].

О. Уздинська висловлює думку про те, що “молодіжний сленг становить собою особливу підмову в складі загальнонаціональної мови. Молодь у віці від 14 до 25 років використовують сленг для спілкування, вважаючи, що вносячи у своє мовлення сленгові слова, вони наближаються до співбесідників, створюють атмосферу невимушеності та відкритості" [17].

С. Пиркало, Л. Ставицька, О. Уздинська виокремлюють три групи молодіжної сленгової лексики. Першу групу формують сленгові номінації метафоричного характеру, які називають предмети чи осіб або характеризують їх. Сюди належать загальновживані слова, що використовуються в новому значенні, наприклад: валянок бездіяльна людина; баџила - людина, котра заважає кому-небудь, дятел - обмежена людина; специназ - вахтери в гуртожитку; порба - кінець і т. под. Другу групу сленгових одиниць складають лексеми зі зменшено-пестливим значенням на зразок: компік (комп'ютер), бабулссики (гроші), пивасик (пиво), тралік, (тролейбус) та ін. Третю групу формують переважно дієслова та прикметники, зрідка іменники, смисл яких вкладено в поняття "інтенсивність" та "надмірність": злиняти, здибатись, в'їхати, відиити, відморозити, кумарити, припухати, приколотися, задрати, борзий, прищиблений та ін. [12, с. 27].

Варто зазначити, що у молодіжному сленгові діють ті ж закономірності, що і у нормативній мові, зокрема, лексеми вступають у синонімічні, антонімічні, омонімічні відносини. Так, літературне слово "хлопець" має такі жаргонні відповідники: “покемон”, “кадр”, “пациик”, “ильоцикк”, “хіляк” (слабкий фізично), “ларик” (відмінник), “васьок” (незнайомий). Крім того, якщо хлопець має якусь виражену позитивну чи негативну якість, він може бути названий “молоток” (добрий, розумний); “плуг” (тугодум); “Леопольд” (доброзичливий); “му-му” (мовчун) [16].

У процесі творення молодіжного сленгу поширеним $є$ мовний закон економії лексичних засобів. Так, відоме в українському мовленні слово $O K$ походить від англомовного словосполучення all correct - все правильно. На ввічливе привітання приятельки та іiі питання про здоров'я, справи прийнято відповідати: “Усе ОК”, навіть якщо зовсім не $O K$. Це слово розуміють майже в усіх, у тому числі неангломовних країнах, але в діловому мовленні його уникають. $O K$ означає: " $Я$ 6 порядку, здоровий, все в нормі, добре, правильно”. Також одним із поширених сленгових виразів англійської мови $є$ cool. У словниках подано лише один варіант перекладу цього слова - "холодний", "прохолодний", але у повсякденному спілкуванні cool використовують у значенні: “Чудово! Клас! Прекрасио!".

У ході спостережень за мовленням студентів було констатовано морфологічні помилки під час відмінювання іменників чоловічого роду другої відміни, зокрема, форми родового відмінка однини: поблизу гуртожитка; біля деканата; рівень інтелекта та ін. Багато помилок пов'язано з утворенням форми кличного відмінка власних імен, імен по батькові, яку студенти зазвичай замінюють формою називного відмінка. Порушувались морфологічні норми у процесі творення активних i пасивних дієприкметників, наприклад: бувиий декан, говорячий студент, задіяний у проєкті студент та інші.

На уроках математики у початковій школі студенти під час педагогічної практики часто утворюють неправильні відмінкові форми власне кількісних та дробових числівників, порушують норми сполучення числівників 3 іменниками. 
Труднощі виникають у процесі творення відмінкових форм складних числівників, що закінчуються на -десят, -сот. Наприклад, n'ятидесяти, шестистами (правильно: n'ятдесяти, иістьмастами, иістьомастами).

На сучасному етапі розширюється соціокультурний простір інтернетного спілкування. Дослідження соціальних мереж та мови спілкування всередині них, проведене різними соціологічними групами, засвідчило, що на українськомовних версіях відомих соціальних мереж (Twitter, Facebook та ін.) лише $7 \%$ користувачів залишають повідомлення (новини, статуси) українською мовою. Фахівці Київського міжнародного інституту соціології стверджують, що суржиком спілкуються і пишуть від $11 \%$ до 18 \% українців, більшість інформації (85\%), що подається у соціальних мережах, російськомовна. Частка україномовної інформації становить лише $15 \%$ [19].

Здебільшого спілкування у соціальній мережі “Facebook" $є$ продовженням реального спілкування. Через відсутність безпосереднього контакту і неможливість використання невербальних засобів спостерігаємо надмірну кількість непотрібних розділових знаків (навіщо????777, нічого собі !!!!!!!, ти де?????, ти зиасщ .... я хотів .... попросити тебе ....). Окрім того, інформація подається без розрізнення великих і малих літер (поӥду в київ, він в америці, ромки сьогодні не було). Через неможливість використання екстралінгвальних засобів (голосу, тембру, тональності) використовують великі літери на позначення наголосів у словах (прошУ, шкодА, mОму) чи для посилення емоційності та експресивності (AАAAAaаaаУУУуyу! ПроШШШШу! ДАААAАAци!) [9]. Крім цього, для вираження своїх почуттів, емоцій та психічного стану використовуються смайлики. Тому в мовленні користувачів соціальних мереж переважають прості, означено-особові речення (Іду в магазин; був в універі; сиджу за компом). Крім цього, дуже часто використовуються скорочення слів (ок, норм, дяки). Ці моделі інтернетної комунікації активно переносяться і на повсякденне спілкування сучасних студентів. Мовці віком від 15 до 25 років, які шодня спілкуються у соціальних мережах у процесі безпосереднього спілкування використовують 80 \% лексики, яка виникла і побутує в соціальних мережах.

Звичайно, не можна говорити лише про негативний вплив інтернетного мовлення на мовлення студентів. Так, інтернетний сайт Gazeta.Ua розмістила статтю "10 цікавих фактів про українську мову" [6]. Поряд із цим інтернетні мережі розміщують посилання на доступ до електронних версій літератури ("Найбільші списки електронних бібліотек в Інтернеті", “Безкоштовні онлайн бібліотеки. Завантажуй і читай” та ін.). В інтернетних мережах організовуються онлайн-курси для тих, хто бажає вивчити українську мову, наприклад, “СловОпис" [15]. Також у "Facebook" можна знайти сторінки, які популяризують українську мову і культуру ("Ukrainian Language and Culture School", "Чиста Мова", "Українська мова", "Вивчай українську!” та інші). Подібні інтернет-сайти містять інформацію, що може бути корисною для майбутніх учителів початкової школи, які прагнуть удосконалювати культуру свого мовлення (як реального, так і віртуального).

Одним із поширених джерел підвищення культури мовлення студентів прийнято вважати читання художньої літератури. Безсумнівно, читання творів художньої літератури допоможе збагатити словниковий запас, зробити мовлення образним і змістовним, проте варто бути пильними, читаючи художню літературу сучасних письменників. Так, сленг i жаргон трапляються в текстах творів Ю. Андруховича, О. Забужко, С. Жадана, Л. Дереша та інших. У творі "Архе" Л. Дереш вживає жаргонну лексику, пояснюючи це тим, що вона допомагає 
створити світ індивідуальних смислів та естетичних узагальнень, надає тексту експресивного забарвлення [5]. Статусу сленгізмів набувають елементи польської розмовної, діалектної лексики та фразеології, що засвоюються в готовому вигляді або набувають семантичних граматичних трансформацій. Наприклад, запозичене 3 польської мови діалектне слово фраср (frajer - залицяльник) в молодіжному сленгу набуває нових відтінків значення: “наӥвна недосвідчена людина", або "людина, яка багато із себе вдає і дуже себе любить": "Фраєра-горе-баригу Терезка підстерегла mам”. Слово крутий, запозичене з американського розмовного tough, cool, означає "неординарний, екстраординарний”: "Він найкрутіший $i$ найзадупленіший чувак $у$ यілому Львові [5, с. 160, 190]. Лексичної трансформації зазнають загальномовні фразеологізми, елементи яких в усно-розмовній невимушеній комунікації можуть заміщатися жаргонізмами: “Одна з них буха в дим, і ій начебто соромно” [5, с. 257]; "Я дещо знітився: устами дитини гундосить істина" [5, с. 233]; "Так ми всі в осад $i$ випали" [5, с. 111]. У творі експресивно-стилістичну функцію виконують слова, що виражають негативні емоції: “... що то капеџь! Боже, ЦЕ КАПУТ! ” [5, с. 162].

У романі “Депеш Мод” С. Жадан активно використовує усталені й зрозумілі в молодіжному середовищі мовні формули спілкування, жаргони (ладж-сором, стрьомно, бабки та ін.), наприклад: "Какао дещуо за товстий для цієё компанії, $і$ в костюмі свосму виглядає стрьомно..." [7].

Жаргонна лексика має свої особливості вживання і в "Рекреаціях" [2] та "Московіаді" [1] Ю. Андруховича. Здебільшого переважають іменники (пацан, морда, рило, синуля, лягабка, мудило, ильондра, наплечники, бухло, імбецил, петеушник, студентик, мармиза), дієслова (вигрібатися, цмулити, гонити, сікти, дудлити, процвиндрити, пензлювати), рідко трапляються прикметники: иизанутий ("Рекреаціі"), лажсовии, забімбаний.

Аналіз лінгвістичної та лінгводидактичної літератури, вивчення думок науковців дозволяють нам стверджувати про те, що досягти високої культури мовлення сучасна молодь зможе за умови вдумливо читання художньої, наукової, публіцистичної літератури, лінгвістичних словників, критичного реагування на якість ретрансляційної продукції. Крім того, майбутній учитель початкової школи повинен дотримуватись таких правил: 1) протистояти вживанню жаргонізмів, вульгаризмів, слів-паразитів, суржику, сленгу як у школі, так і поза школою; 2) дбати про грамотне оформлення плакатів, вивісок, стінних газет, оголошень, класної дошки, шкільної документації; 3) чітко продумувати хід викладу матеріалу на уроках, щоб паузи не заповнювались ненормативною лексикою; 4) постійно контролювати власне мовленням: уникати неправильно побудованих речень i зворотів, порушень норм літературної вимови, неточностей у формулюванні визначень і недбалості у виборі слів.

Висновки та перспективи подальших досліджень... Отже, у процесі професійно-практичної підготовки майбутніх учителів початкової школи формування мовленнєвих умінь і правописних навичок посідає особливе місце, оскільки досконале володіння культурою спілкування $€$ важливим показником освіченості, духовності й фахової підготовки студентів закладів вищої педагогічної освіти. Студенти педагогічного факультету повинні досконало знати норми сучасної української літературної мови, уміти користуватися академічними лінгвістичними словниками української мови, стежити за правильністю усного та писемного мовлення. Аналіз фонетичних, лексичних, граматичних, стилістичних, орфографічних, пунктуаційних помилок, робота над їх усуненням - обов'язок майбутнього вчи- 
теля початкової школи. Лише та освічена молода людина досягне успіху в житті, створить успішну кар'єру, яка вільно володіє літературною мовою, вміє переконати співрозмовника без використання сленгових слів та ненормативної лексики. Крім того, сучасна молодь несе культуру усного та писемного мовлення в освітній простір, професійне й побутове спілкування та формує комунікативний простір навколо себе.

Література

1. Андрухович Ю. Московіада. Івано-Франківськ: Лілея-НБ, 2006.151 с.

2. Андрухович Ю. Рекреації. Романи. Київ: Час, 1997. 287 с.

3. Бабич Н. Д. Основи культури мовлення. Львів: Світ, 1990. 232 с.

4. Вашуленко М. Мовленнєва підготовка вчителя початкових класів [Електрон. ресурс.] Режим доступу: http://library.udpu.org.ua/ library_files/psuh_pedagog_probl_silsk_shkolu/1/ visnuk_20.pdf (дата звернення: 15.07.2019).

5. Дереш Л. Архе. Харків: Фоліо, 2007. 319 с.

6. Десять цікавих фактів про українську мову [Електронний ресурс]. Режим доступу : http://gazeta.ua/articles/history/_10-cikavih-faktiv-pro-ukrayinsku-movu/657994 (дата звернення: 15.07.2019).

7. Жадан С. Депеш Мод. Харків : Фоліо, 2009. 240 с.

8. Закон України "Про забезпечення функціонування української мови як державної" від 25 квітня 2019 р. № 2704-VIII: https://zakon.rada.gov.ua/go/2704-19 (дата звернення: 05.07.2019).

9. Маковецька-Гудзь Ю. А. Українська мова в соціальних мережах [Електронний ресурс] / Режим доступу: http://philology.knu.ua/files/library/movni_i_konceptualni/47-1/77.pdf (дата звернення: 17.07.2019).

10. Огієнко І. Наука про рідномовні обов'язки. Київ: Обереги, 1994. 44 с.

11. Перетокіна В. Ф. Англійський молодіжний сленг та його переклад. Англістика та американістика. Дніпропетровський національний університет імені Олеся Гончара. 2013. Випуск 10. С. 129-133.

12. Пиркало С. Сленг: ненормативно, але нормально. Урок украйнської. 2000. № 4. С. 26-28.

13. Радчук В. Суржик як недопереклад. Украйнська мова та література в школі. 2000. № 2. С. 11.

14. Селіванова О. Сучасна лінгвістика : термінологічна енциклопедія. Київ, 2006.716 c.

15. СловОпис [Електронний ресурс]. Режим доступу: https://www.youtube.com/ watch? $\mathrm{v}=\mathrm{eKdHwBISs} 0 \mathrm{I}$ (дата звернення: 18.07.2019).

16. Ставицька Л. Арго, жаргон, сленг. Київ: Критика, 2005. 494 с.

17. Уздинская Е. В. Семантическое своеобразие современного жаргона. Саратов, 1991. 210 с.

18. Український правопис. https://законодавство.com/ministriv-kabineta-postanovi/ postanova-vidtravnya-2019-437-pitannya-2019-71792.html. (дата звернення: 18.07.2019).

19. Чемеркін С. Г. Українська мова в Інтернеті: позамовні та внутрішньо-структурні процеси. Київ, 2009. 240 c.

\section{References}

1. Andrukhovych Yu. Moskoviada. Ivano-Frankivsk: Lileia-NB, $2006.151 \mathrm{~s}$.

2. Andrukhovych Yu. Rekreatsii. Romany. Kyiv: Chas, 1997. 287 s.

3. Babych N. D. Osnovy kultury movlennia. Lviv: Svit, 1990. $232 \mathrm{~s}$.

4. Vashulenko M. Movlennieva pidhotovka vchytelia pochatkovykh klasiv [Elektron. resurs.] Rezhym dostupu: http://library.udpu.org.ua/ library_files/psuh_pedagog_probl_silsk_shkolu/1/ visnuk_20.pdf (data zvernennia: 15.07.2019).

5. Deresh L. Arkhe. Kharkiv: Folio, 2007. 319 s.

6. Desiat tsikavykh faktiv pro ukrainsku movu [Elektronnyi resurs]. Rezhym dostupu : http://gazeta.ua/articles/history/_10-cikavih-faktiv-pro-ukrayinsku-movu/657994 (data zvernennia: 15.07.2019).

7. Zhadan S. Depesh Mod. Kharkiv : Folio, 2009. $240 \mathrm{~s}$.

8. Zakon Ukrainy "Pro zabezpechennia funktsionuvannia ukrainskoi movy yak derzhavnoi" vid 25 kvitnia 2019 r. № 2704-VIII: https://zakon.rada.gov.ua/go/2704-19 (data zvernennia: 05.07.2019). 
9. Makovetska-Hudz Yu. A. Ukrainska mova v sotsialnykh merezhakh [Elektronnyi resurs] / Rezhym dostupu: http://philology.knu.ua/files/library/movni_i_konceptualni/47-1/77.pdf (data zvernennia: 17.07.2019).

10. Ohiienko I. Nauka pro ridnomovni oboviazky. Kyiv: Oberehy, 1994. $44 \mathrm{~s}$.

11. Peretokina V. F. Anhliiskyi molodizhnyi slenh ta yoho pereklad. Anhlistyka ta amerykanistyka. Dnipropetrovskyi natsionalnyi universytet imeni Olesia Honchara. 2013. Vypusk 10. S. 129-133.

12. Pyrkalo S. Slenh: nenormatyvno, ale normalno. Urok ukrainskoi. 2000. № 4. S. 26-28.

13. Radchuk V. Surzhyk yak nedopereklad. Ukrainska mova ta literatura v shkoli. 2000. № 2. S.

14. Selivanova O. Suchasna linhvistyka : terminolohichna entsyklopediia. Kyiv, 2006. $716 \mathrm{~s}$.

15. ClovOpys [Elektronnyi resurs]. Rezhym dostupu: https://www.youtube. com/watch? $v=\mathrm{eKdHwBISs0I}$ (data zvernennia: 18.07.2019).

16. Stavytska L. Arho, zharhon, slenh. Kyiv: Krytyka, 2005. 494 s.

17. Uzdynskaia E. V. Semantycheskoe svoeobrazye sovremennoho zharhona. Saratov, 1991. $210 \mathrm{~s}$.

18. Ukrainskyi pravopys. https://zakonodavstvo.com/ministriv-kabineta-postanovi/ postanova-vidtravnya-2019-437-pitannya-2019-71792.html. (data zvernennia: 18.07.2019).

19. Chemerkin S. H. Ukrainska mova v Interneti: pozamovni ta vnutrishno-strukturni protsesy. Kyiv, 2009. $240 \mathrm{~s}$.

Одержано статтю: 15.10 .2019

Прийнято до друку: 5.11.2019

УДК $378.016: 338.46$

DOI: $10.15330 /$ esu. 17.236-244

\author{
Юрій Завалевський, \\ доктор педагогічних наук, професор, \\ Інститут модернізації змісту освіти \\ (м. Київ, Україна) \\ Yurii Zavalevskyi, \\ Doctor of pedagogical sciences, Professor, \\ Institute of Education Content Modernization \\ (Kyiv, Ukraine) \\ zuil@imzo.gov.ua
}

\section{ФОРМУВАННЯ КОНКУРЕНТОСПРОМОЖНОСТІ МАЙБУТНЬОГО ФАХІВЦЯ СФЕРИ ПОСЛУГ}

\section{FORMING OF COMPETITIVENESS OF THE FUTURE SPHERE OF SERVICES SPECIALIST}

Дослідження сфокусовано на з'ясування особливостей формування конкурентоспроможності майбутнього фахівия сфери послуг в сучасних закладах професійнотехнічної освіти. Зауважено на необхідності подолання суперечності між важливістю подолання потреби економіки у конкурентоспроможних кваліфікованих робітниках $i$ недостатнім теоретико - методичним забезпечениям педагогічного прочесу формувания иієї якості у майбутніх фахівиів сфери послуг. Зроблено висновок про те, ио професійнотехнічним закладам освіти потрібно формувати систему зазначених ключових якостей майбутнього конкурентоспроможного фахівия сфери послуг та створювати освітні умови за яких буде формуватися його конкурентоспроможність.

Ключові слова: конкурентоспроможність, конкурентоспроможна особистість майбутнього фахівця, фахівечь сфери послуг, соціальні особистісні якості фахівия, психологічних, когнітивних та поведінкові якості.

The research is focused on researching the peculiarities of the competitiveness formation of the future professional of the service industry at modern vocational education establishments. The necessity of overcoming the contradiction between the importance of meeting the needs of the economy in competitive skilled workers and insufficient theoretical and methodological support of 